\title{
Effect of dihydrotestosterone on the growth and function of ovarian follicles in intact immature female rats primed with PMSG*
}

\author{
B. A. Conway, V. B. Mahesh and T. M. Mills \\ Department of Physiology and Endocrinology, Medical College of Georgia, Augusta, \\ Georgia 30912-3000, USA
}

\begin{abstract}
Summary. Intact, immature female rats were primed with PMSG and treated with 4 injections of DHT. DHT given at $0,12,24$ and $36 \mathrm{~h}$ caused a significant decrease in the ovulation rate $72 \mathrm{~h}$ after the PMSG treatment. Concurrent treatment with oestrogen reversed the inhibitory effects of the androgen. The androgen effect was apparently exerted directly on the ovary since DHT did not alter the surge of LH and FSH which occurred at $58 \mathrm{~h}$ after PMSG treatment. The DHT inhibition of ovulation was observed in the treatment cycle as well as in subsequent cycles which followed a second PMSG injection. This finding suggests that intermediate size follicles were also adversely affected by the androgen. To confirm that androgen affects follicles of all size ranges, follicles $<200 \mu \mathrm{m}, 200-400 \mu \mathrm{m}$ and $>400 \mu \mathrm{m}$ in diameter were isolated from the ovaries of rats treated with PMSG and DHT or the vehicle. The follicles were isolated by density gradient separation of follicles followed by filtration with precalibrated Teflon sieves. In some experiments, granulosa cells were also harvested from isolated follicles. DHT treatment did not affect the numbers of follicles of any size but did reduce the oestrogen content of follicles of all sizes. Follicles from DHT-treated animals contained fewer granulosa cells and the cells from treated animals had lower aromatase activity than did cells from control rats. Taken together, these findings suggest that DHT reduces the ovulation rate by decreasing the number of granulosa cells/follicle and by altering the oestrogen synthetic abilities of the cells. All follicles, regardless of size, were sensitive to androgen treatment.
\end{abstract}

Keywords: androgen; dihydrotestosterone; follicle growth; ovulation; PMSG; rat

\section{Introduction}

While the ultimate fate of the majority of ovarian follicles is atretic degeneration (Byskov, 1978), factors which regulate atresia are poorly understood. Ovarian steroids may alter the folliculogenic processes and, in doing so, alter the rate of atresia (Goodman \& Hodgen, 1983). Androgens have been reported to be inhibitory (Louvet et al., 1975; Farookhi, 1980; Bagnell et al., 1982) or stimulatory (Hillier \& Ross, 1979) to follicular development; the action appears to depend on the androgen used and the dosage and duration of treatment. Dihydrotestosterone (DHT) specifically inhibits the FSH induction of LH receptors in granulosa cells (Farookhi, 1980; Jia et al., 1985), possibly leading to follicular atresia if the follicles fail to ovulate. On the other hand, oestradiol, when administered to PMSG-primed hypophysectomized immature rats, amplifies the responsiveness of ovarian follicles to gonadotrophic stimulation (Richards, 1979). Oestradiol has also been reported to increase ovarian weight and to decrease the rate of atresia (Harman et al., 1975).

\footnotetext{
*Reprint requests to: Thomas M. Mills.
} 
A previous publication from this laboratory reported that DHT treatment of hypophysectomized immature rats was marked by inhibition of both follicular growth and ovulation (Bagnell et al., 1982). These results have been challenged (Kohut et al., 1985), and the following study was undertaken: (1) to confirm that DHT inhibits follicle growth, (2) to show that DHT affects the development not only of large follicles but also of follicles of other sizes, and (3) to demonstrate that the androgen acts to reduce the rate of oestrogen synthesis in granulosa cells from all sizes of follicles.

\section{Materials and Methods}

Animals. Intact, immature, female Sprague-Dawley rats were obtained from Holtzman Laboratories (Madison, WI, USA) and were housed in a temperature-controlled $\left(22^{\circ} \mathrm{C}\right)$ room with a $14 \mathrm{~h}$ light/10 h dark environment $(05: 00-$ 19:00, EST). Animals were caged in groups of 4 or 5 and provided with rat chow and tap water ad libitum. Pregnant mares' serum gonadotrophin (PMSG; biological potency $=2000 \mathrm{i} . \mathrm{u} . / \mathrm{mg}$; NICHD-Contraceptive Development Branch; G. Bialy) was injected ( 8 i.u. in 0.2 ml saline) between 06:00 and 07:00 h. Steroid (Steraloids: Wilton, NH, USA) injections were given at $0,12,24$ and $36 \mathrm{~h}$ and included various doses of DHT $(0,0.25,0.5,1.0$ and $2.0 \mathrm{mg} / \mathrm{kg}$ body weight), oestradiol ( $1 \mathrm{mg} / \mathrm{kg}$ body weight), a combination of both DHT and oestradiol (1 mg each hormone/ $\mathrm{kg}$ body weight) or the injection vehicle only. The steroid vehicle was propylene glycol and the volume of each injection was $0.1 \mathrm{ml}$. Rats were killed by decapitation and, in some experiments, trunk blood was collected. When rats were killed at $72 \mathrm{~h}$, the number of ova present in the oviduct was counted according to the method of Burdick $\&$ Whitney (1941) as a measure of the ovulation rate. Animals which were not killed at $72 \mathrm{~h}$ (Cycle 1 ), received a second injection of 8 i.u. PMSG at $104 \mathrm{~h}$ : they were then killed at $120 \mathrm{~h}$ (Intermediate Cycle) or at $178 \mathrm{~h}$ (Cycle 2) after the initial PMSG and ova were counted.

Histology of the ovaries. To count the number and size distribution of follicles present, ovaries were fixed in Bouin's fluid, dehydrated and infiltrated with paraffin wax. The ovaries were sectioned serially at $8 \mu \mathrm{m}$ and sections stained with haematoxylin and eosin. The follicles were classified as primary, secondary or tertiary according to the criteria of Pederson \& Peters (1968) with atretic follicles identified by the method of Byskov (1978). Every section was examined and follicles were counted and classified only in the cross-section which included the germinal vesicle to avoid duplicate counting.

Radioimmunoassay of gonadotrophins. Blood was allowed to clot and the resulting serum frozen for gonadotrophin assay. Concentrations of serum LH and FSH were determined by the double-antibody RIA method as described by O'Connor et al. (1982) and Rao \& Mahesh (1986). Purified LH and FSH standards and first antibody for LH (rLH-S7) and FSH (rFSH-S11) were obtained from the National Hormone and Pituitary Program of the National Institute of Diabetes, Digestive and Kidney Disease. The second antibody was purchased from Arnell, Inc. (Brooklyn, NY, USA) and used at a final dilution of 1:250. The iodination procedure generally yielded specific activities in the range of $25-50 \mu \mathrm{Ci} / \mu \mathrm{g}$ for ${ }^{125} \mathrm{I}$-labelled $\mathrm{LH}$ and $65-90 \mu \mathrm{Ci} / \mu \mathrm{g}$ for ${ }^{125} \mathrm{I}$-labelled FSH. The labelled gonadotrophins were diluted to a final concentration of 30000 c.p.m. $/ 0.1 \mathrm{ml}$. At 1:10000 and 1:15000 dilutions for LH and FSH antisera, respectively, 23-26\% binding was obtained. The intra- and interassay coefficient of variation values were $9.6 \%$ and $11.0 \%$ for $\mathrm{LH}$ and $5 \cdot 1 \%$ and $10.2 \%$ for FSH. Hormone values were expressed in terms of the NIAMDD-RP-1 standards for LH and FSH.

Follicle isolation. A modification of the follicle isolation method of Roy \& Greenwald (1985) was used to isolate and purify follicles from rat ovaries. Preliminary experiments established the optimal concentration of collagenase and duration of the incubations to yield the maximal number of follicles. Ovaries were manually teased into small pieces before exposure to a prewarmed mixture containing $4800 \mathrm{U}$ collagenase (Sigma Type I: $482 \mathrm{units} / \mathrm{mg}$ solid in $1.5 \mathrm{ml} \mathrm{McCoy's} 5 \mathrm{~A}+25 \mu \mathrm{M} \cdot$ Hepes) and $200 \mathrm{U}$ DNase (Sigma, bovine pancreas III; $1350 \mathrm{Kunitz} / \mathrm{mg} \mathrm{solid} \mathrm{in} 0.5 \mathrm{ml}$ McCoy's 5A) plus $0.5 \mathrm{ml} 1 \% \mathrm{BSA}$ in McCoy's SA. The incubations were carried out at $35^{\circ} \mathrm{C}$ for a total of $20 \mathrm{~min}$ with brief agitation of the mixture after $10 \mathrm{~min}$. Following the incubation, $1.0 \mathrm{ml}$ McCoy's $5 \mathrm{~A}$ with $1.5 \%$ BSA was added and the tube centrifuged at $45 \mathrm{~g}$ for $3 \mathrm{~min}$. The supernatant was discarded, the follicles washed with fresh McCoy's $5 \mathrm{~A}$ and again centrifuged for $3 \mathrm{~min}$ at $45 \mathrm{~g}$. The supernatant was discarded and the follicles resuspended in $1.0 \mathrm{ml}$ McCoy's 5A. The suspension was next layered onto a 10-50\% Percoll (Pharmacia) gradient (total gradient volume $=32 \mathrm{ml}$ ) and centrifuged at $45 \mathrm{~g}$ for $3 \mathrm{~min}$ at $4^{\circ} \mathrm{C}$. The gradient was fractionated into 2-ml samples and an additional $2 \mathrm{ml}$ McCoy's $5 \mathrm{~A}$ were added to each fraction to dilute the Percoll. The fractions were centrifuged at $45 \mathrm{~g}$ for $3 \mathrm{~min}$ at $4^{\circ} \mathrm{C}$ and the supernatant was discarded. Partly purified follicles in each fraction were resuspended in $2.0 \mathrm{ml} \mathrm{McCoy's} 5 \mathrm{~A}$ with $0.1 \%$ BSA and a $100-\mu \mathrm{l}$ sample was examined at $\times 40$ magnification to determine the follicle size range present in each fraction. Fractions 1 and 2 were found to contain dead granulosa cells; fractions 3-5 contained predominantly follicles $<200 \mu \mathrm{m}$ in diameter; fractions 6-12 contained follicles with diameters of $200-400 \mu \mathrm{m}$; fractions $13-15$ contained follicles $>400 \mu \mathrm{m}$ in diameter; fractions $16-18$ contained follicular debris and damaged follicles. Fractions 3 through 5, 6 through 12 and 13 through 15 were pooled and each pool was passed through precalibrated Teflon sieves (Micromesh, Fisher Scientific, Pittsburgh, PA, USA) with mesh sizes of $72 \mu \mathrm{m}$, $210 \mu \mathrm{m}$ and $420 \mu \mathrm{m}$. In this manner, follicles were isolated according to size: small follicles $(<200 \mu \mathrm{m})$, medium follicles $(200-400 \mu \mathrm{m})$ and large follicles $(>400 \mu \mathrm{m})$. The principal improvement in this modification is the speed with 
which large numbers of follicles can be harvested; the method of Roy \& Greenwald (1985) required about $6 \mathrm{~h}$ to collect follicles while a similar number of follicles could be obtained in approximately 30 min using the Percoll gradient and Teflon sieves. Because the follicles were isolated quickly, the viability of the granulosa cells in the follicles remained high.

Oestrogen assay. Follicles in each group were suspended in $1 \mathrm{ml}$ water and homogenized with an all-glass homogenizer. The steroids were extracted with ether and the oestrogen content determined by specific radioimmunoassay as previously described by Melner \& Abney (1980) using the TG $\mathrm{E}_{2} \mathrm{~K}$ antibody obtained from Professor Delwood Collins of Emory University, Atlanta, Georgia, USA. The intra- and interassay coefficients of variation for this assay were $6.3 \%$ and $11.4 \%$, respectively.

Granulosa cell isolation. In some studies, the granulosa cells were harvested from the isolated follicles using a modification of the method of Campbell (1979). In this procedure, isolated follicles were covered with McCoy's 5A buffer containing $6.8 \mathrm{~mm}$-EGTA and $0.2 \% \mathrm{BSA}$ and incubated for $10 \mathrm{~min}$ at $37 \% \mathrm{C}$ in a $95 \% \mathrm{O}_{2}-5 \% \mathrm{CO}_{2}$ atmosphere. The follicle suspension was centrifuged at $65 \mathrm{~g}$ for $5 \mathrm{~min}$, the supernatant discarded and the resulting pellet covered with McCoys $5 \mathrm{~A}$ with $0.5 \mathrm{M}$-sucrose and $1.8 \mathrm{mM}$-EGTA and incubated for an additional $5 \mathrm{~min}$. Three volumes of the McCoy's 5A buffer without sucrose were added and the fractions centrifuged. The supernatants were discarded and the peilets resuspended in McCoy's $5 \mathrm{~A}$ with $0.2 \% \mathrm{BSA}$. The follicles in each fraction were gently pressed with a Teflon pestle to rupture them and to express the granulosa cells. The resulting freed granulosa cells were concentrated by centrifugation and then resuspended in McCoys $5 \mathrm{~A}$ buffer containing $0 \cdot 1 \% \mathrm{BSA}$. An aliquant was taken to count the total number of granulosa cells in each fraction using a haemocytometer. Viability was determined by exclusion of erythrosin B.

Aromatase assay. Viable granulosa cells $\left(75 \times 10^{6}\right)$ in $450 \mu 10.05 \mathrm{M}$-phosphate buffer $(\mathrm{pH} 7.4)$ were incubated for 0,30 and $60 \mathrm{~min}$ with $0.5 \mu \mathrm{M}$-testosterone and an NADPH-generating sysem $(0.27$ mm reduced $\beta$-nicotinamide adenine dinucleotide phosphate (NADPH), $0.3 \mathrm{~mm}$ reduced $\beta$-nicotinamide adenine dinucleotide (NADH), $3.8 \mathrm{~mm}$ glucose 6-phosphate, $10 \mathrm{i} . \mathrm{u}$. glucose 6-phosphate dehydrogenase and $2 \mathrm{~mm}$-adenosine triphosphate (ATP) in a total volume of $0.65 \mathrm{ml}$ ). The reaction was stopped by placing the incubation tubes in boiling water for 5 min. The oestradiol produced during the assay was extracted with ether and quantities determined by radioimmunoassay. The relationship between the time of incubation and the amount of oestradiol formed was linear over the 60-min incubation period. As an additional control, granulosa cells from each treatment and size group were boiled and then assayed for aromatase activity with the resulting value subtracted from the 0,30 and 60 min incubation values. The results of this experiment were analysed by analysis of covariance to control for the variability in enzyme activity which exists between the granulosa cells collected from different batches of rats.

Statistics. The results of the remainder of these studies were analysed by one-way and two-way analysis of variance (ANOVA). When significant interactions were found, Tukey's post hoc test (1949) was used.

\section{Results}

\section{Animal studies}

When rats were injected with doses of DHT ranging from 0.25 to $2.0 \mathrm{mg} / \mathrm{kg}$ body weight, the percentage of rats that ovulated and the number of ova shed was reduced significantly only at the dose of $1.0 \mathrm{mg} / \mathrm{kg}$ (Table 1). Accordingly, rats received $1 \mathrm{mg} \mathrm{DHT} / \mathrm{kg}$ in 4 daily doses in all subsequent studies.

Table 1. Effect of increasing doses of DHT on the ovulation rate in rats

\begin{tabular}{lcc}
\hline $\begin{array}{c}\text { Dose of DHT } \\
(\mathrm{mg} / \mathrm{kg})\end{array}$ & \% Ovulation & Ova/rat \\
\hline 0 & 100 & $11 \cdot 8 \pm 0 \cdot 7$ \\
0.25 & 91 & $11 \cdot 0 \pm 0 \cdot 7$ \\
0.5 & 71 & $7 \cdot 8 \pm 0 \cdot 7$ \\
1.0 & $41^{*}$ & $6 \cdot 5 \pm 0.5^{*}$ \\
$2 \cdot 0$ & 55 & $8 \cdot 5 \pm 0.5$ \\
\hline
\end{tabular}

Values are mean \pm s.e.m for $2-4$ experiments with $10-15$ animals in each experiment.

$* P<0.05$ compared with control $(0 \mathrm{mg} / \mathrm{kg})$. 
DHT had little effect on the number of follicles present in the ovaries. Figure I shows that, in serial cross-sections of ovaries from DHT-treated and control rats, there was no significant difference between the number of healthy follicles at all stages of development. However, the number of atretic follicles in the DHT-treated animals was elevated over the number present in ovaries of control rats.

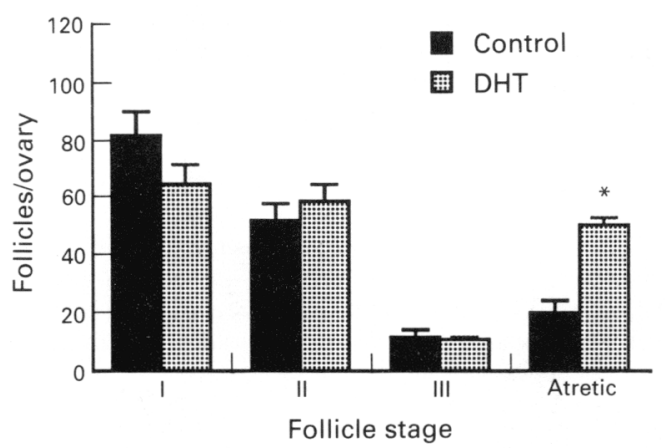

Fig. 1. Population of follicles present in the ovaries of DHT-treated and control rats. Values are mean \pm s.e.m. of follicle counts for 12 ovaries. ${ }^{*} P<0.05$ compared with control.
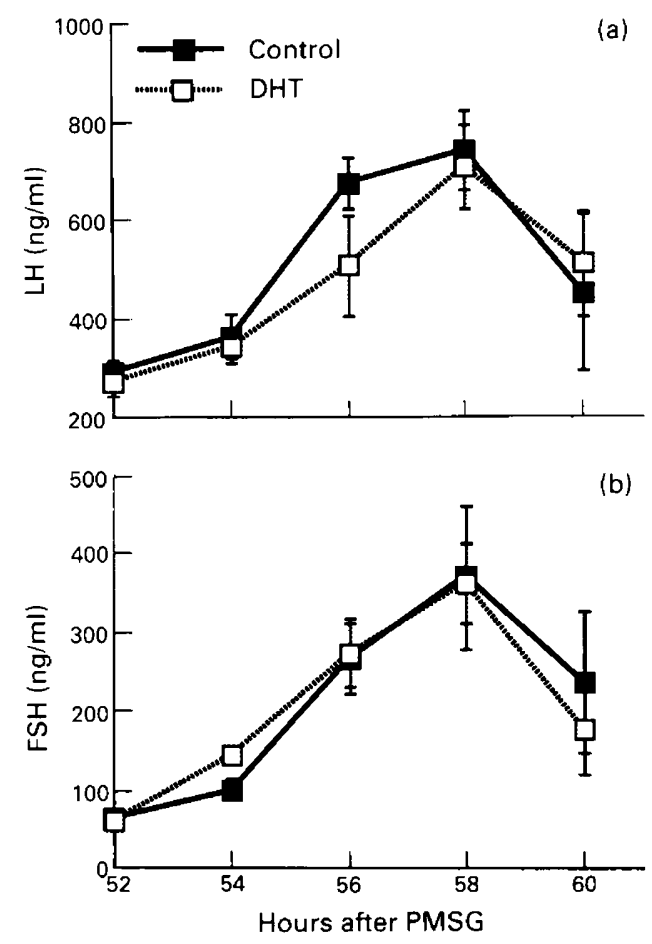

Fig. 2. Effect of DHT treatment on circulating LH (a) and FSH (b) concentrations during the preovulatory period. Values are mean \pm s.e.m. of 4 experiments with 7-15 animals at each time point in each experiment. 
Table 2. Effect of DHT and oestradiol on rates of ovulation in PMSG-primed immature rats

\begin{tabular}{lcl}
\hline Treatment & \% Ovulation & \multicolumn{1}{c}{ Ova/rat } \\
\hline Control & 93 & $8 \cdot 6 \pm 2 \cdot 3$ \\
DHT & $43^{* *}$ & $2 \cdot 3 \pm 1 \cdot 8^{* *}$ \\
Oestradiol & 92 & $8 \cdot 6 \pm 0 \cdot 9$ \\
Oestradiol + DHT & 76 & $8 \cdot 1 \pm 2 \cdot 7$ \\
\hline
\end{tabular}

Values are mean \pm s.e.m of 2 experiments with $12-15$ animals per experiment.

${ }^{* *} P<0.01$ compared with control.

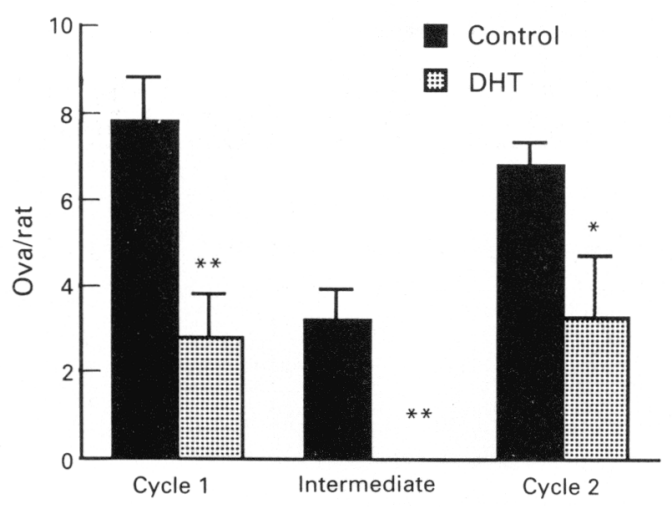

Fig. 3. Effect of DHT on the ovulation rate in Cycle 1, Intermediate Cycle and Cycle 2. Values are mean \pm s.e.m. from 2 experiments each utilizing $6-12$ rats. ${ }^{*} P<0.05,{ }^{* *} P<0.01$ compared with control.

After treatment of immature rats with PMSG and DHT or vehicle, there was a surge of LH and FSH in the interval $52-60 \mathrm{~h}$ after the injection. The results in Fig. 2(a) show a slight difference in the LH pattern between DHT-injected and control animals although analysis of variance proves that the patterns are not different. The patterns of FSH release (Fig. 2b) were identical in the two treatment groups.

Table 2 shows that the administration of $1 \mathrm{mg} / \mathrm{kg}$ dose of oestradiol had no effect on the percentage of rats ovulating or on the number of ova shed per rat. However, when co-administered with DHT, oestradiol completely prevented the androgen inhibition of ovulation.

The next series of studies demonstrated that the inhibitory effect of DHT was not limited only to the large, preovulatory follicles which ovulate at $72 \mathrm{~h}$ after PMSG. Figure 3 shows that the number of ovulations per rat from DHT-treated animals was significantly reduced compared to control rats in the treatment cycle (Cycle 1: $36 \mathrm{~h}$ after the last DHT injection), in the PMSGinduced intermediate cycle ( $84 \mathrm{~h}$ after the last DHT injection), and in the next subsequent cycle (Cycle 2: $142 \mathrm{~h}$ after the last DHT treatment).

\section{Isolated follicle studies}

Using a modification of the follicle isolation procedure of Roy \& Greenwald (1985) combined with the Percoll gradient centrifugation and Teflon sieve filtration, large numbers of follicles were separated. Before the gradient centrifugation and filtration steps, the digestate contained a collection of follicles of all sizes plus ovarian debris and free granulosa cells (Fig. 4a). The steps in 

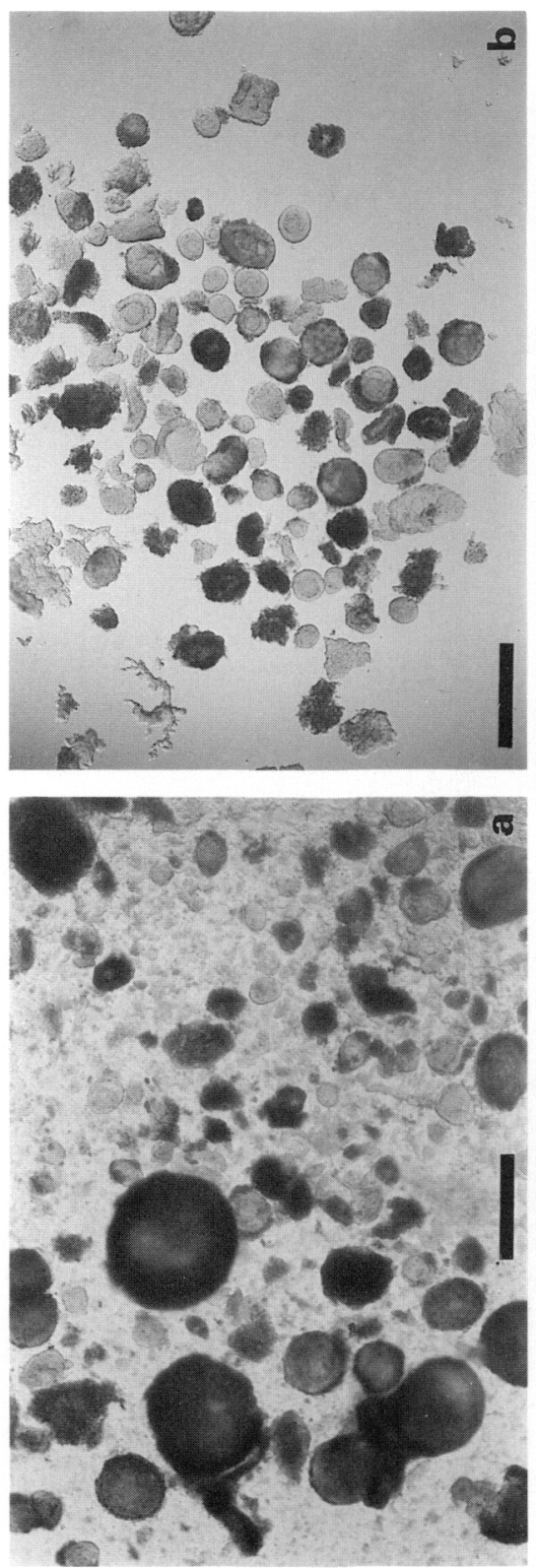
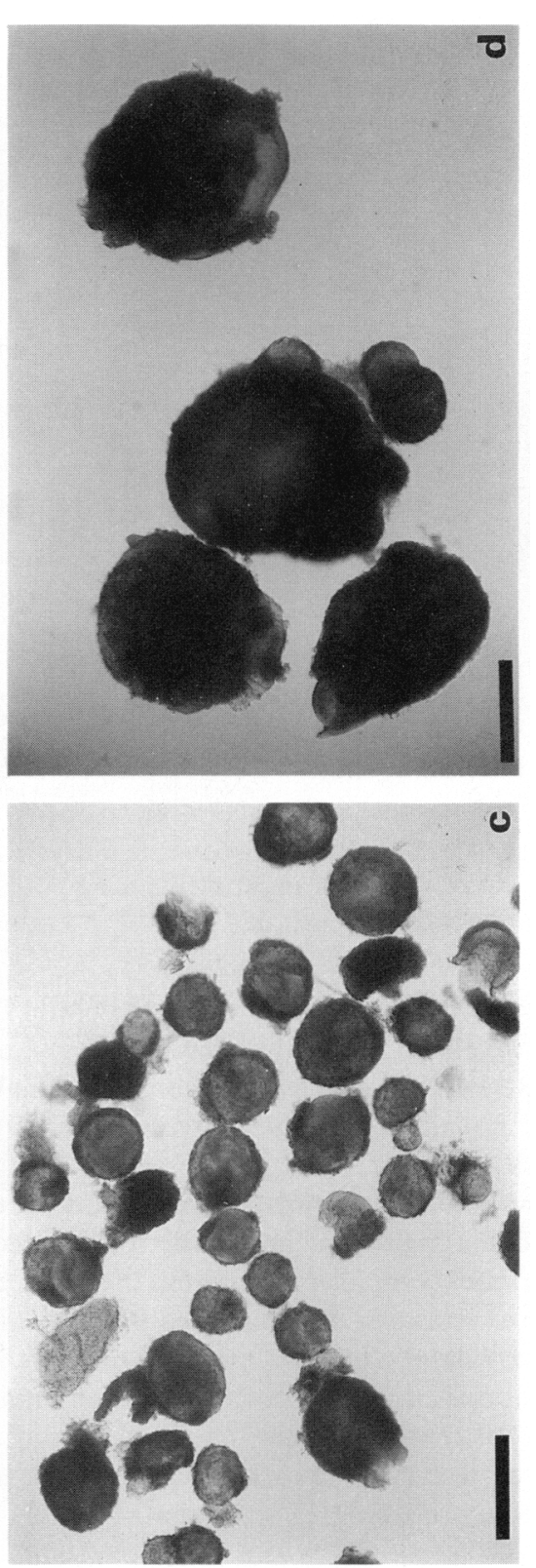

突 $\frac{\mathscr{\alpha}}{\varrho}$

ह

.

蛋官

巳્ฮ

氖

岁焉

这

合它

8

苟

帘岕

8.00

至至

ํํㅇ

ث.

造焉

ปัँ

$3 \cdot \frac{2}{6}$ 曲

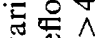
ठ워

ज 踏 응 준 는 옹 웡 . 롱 홍ㅎㅇ용 ठ $\overline{\mathrm{O} V}$ 密 증 \& 원 兽志 노는 $\forall$ 守

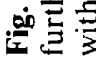



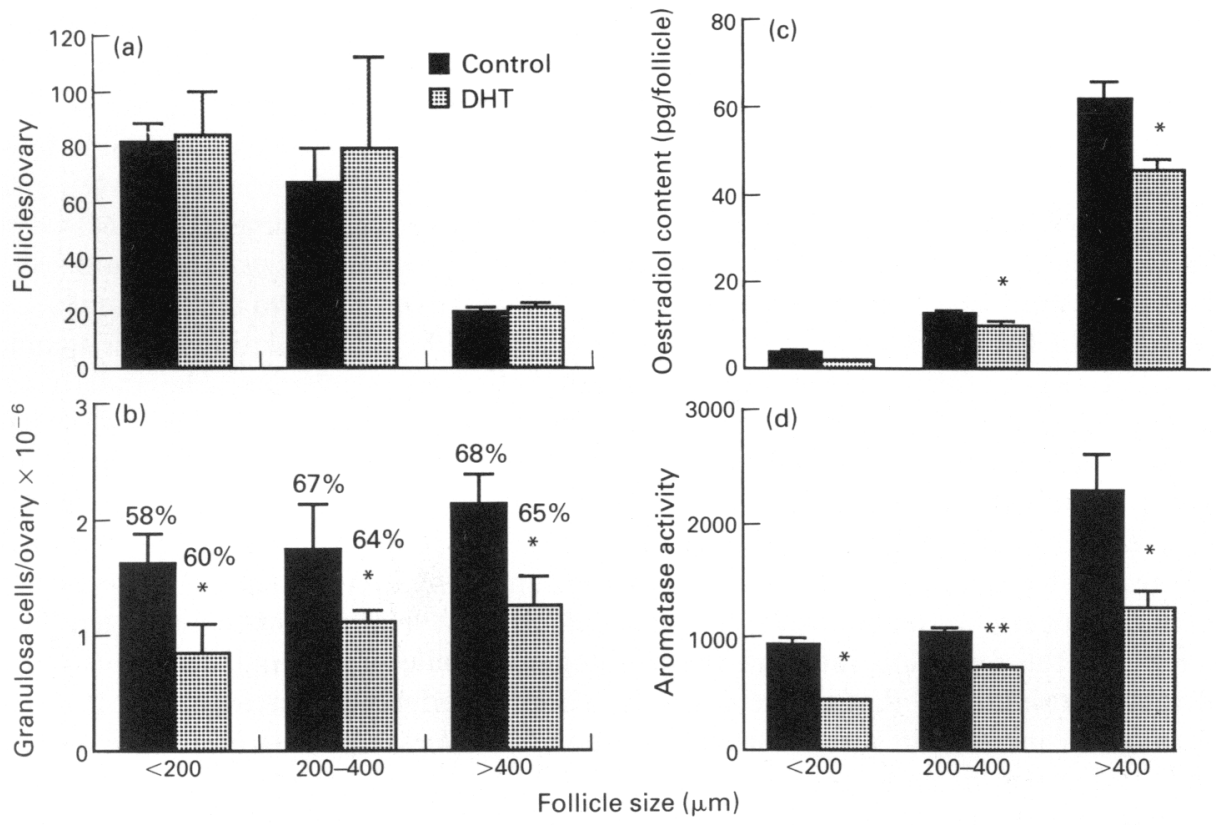

Fig. 5. Effect of DHT on the numbers of follicles (a) and granulosa cells (b), oestradiol content (c) and aromatase activity (d) of granulosa cells harvested from follicles of various sizes from control and DHT-treated rats. Values are mean \pm s.e.m. of 3-5 experiments with 13-16 animals per experiment. In (b), the $\%$ viability is indicated. ${ }^{*} P<0.05,{ }^{* *} P<0.01$ compared with control.

the purification yielded follicles with diameters of $<200 \mu \mathrm{m}, 200-400 \mu \mathrm{m}$ and $>400 \mu \mathrm{m}$ which were largely free of debris and granulosa cell contamination (Figs $4 \mathrm{~b}-4 \mathrm{~d}$ ).

Figure 5(a) shows that DHT did not affect the total number of follicles which could be isolated in each size. These results also show that the total number of follicles/ovary obtained from the isolation procedure was between 150 and 200 . However, despite the similar number of follicles in the treatment groups, the number of granulosa cells which could be isolated was reduced by the androgen treatment in the isolated follicles of all 3 sizes (Fig. 5b). However, DHT did not alter the viability of the existing granulosa cells; viability was generally nearly $60 \%$ or greater.

Dihydrotestosterone treatment significantly reduced the oestrogen content of the follicles. When equal numbers of follicles from DHT-treated and control animals were analysed for oestradiol concentration, the follicles of $>400 \mu \mathrm{m}$ and $200-400 \mu \mathrm{m}$ from the DHT-treated rats contained less oestradiol than did follicles from the control animals (Fig. 5c). Furthermore, DHT treatment caused a significant reduction in aromatase activity in granulosa cells from all sizes of follicles (Fig. 5d).

\section{Discussion}

Conflicting reports exist in the literature as to the effects of androgens on follicular growth and development. Some investigators have used hypophysectomized, oestrogen-treated animals and reported a stimulation of ovarian growth or function with androgens (Hillier \& Ross, 1979). Others have found an inhibition with androgen treatment (Louvet et al., 1975) or no effect of androgens (Kohut et al., 1985). Previously, we showed that DHT inhibited ovulation in PMSG-primed hypophysectomized immature female rats (Bagnell et al., 1982); however, this observation was not confirmed in a subsequent study (Kohut et al., 1985). It is not possible to discern why Kohut $e t$ al. 
(1985) were not able to repeat our results although we feel that the type of PMSG used is of critical importance. Batches of PMSG may vary in their relative LH and FSH activities. To confirm the importance of the type of PMSG used and to validate our previous findings (Bagnell et al., 1982), several PMSG preparations were tested for their ability to stimulate follicular growth in hypophysectomized, immature rats. The ovarian responses proved to be quite variable between and even within the various batches of PMSG (unpublished data). Therefore, the use of the PMSG-treated, hypophysectomized rat model was discontinued. In the present studies which utilized intact PMSG-primed, immature female rats, the response to PMSG was uniform and repeatable.

The results in Table $1 \mathrm{sk}$. iw that, at a dose of $1 \mathrm{mg} \mathrm{DHT} / \mathrm{kg}$, the ovulation rate is significantly reduced while at $2 \mathrm{mg} \mathrm{DHT} / \mathrm{kg}$, the reduction is not statistically significant. The underlying basis for this biphasic effect is not apparent although we previously reported that in the ovarian follicle population of PMSG-treated hypophysectomized, immature rats, treatment with $1 \mathrm{mg}$ DHT/kg significantly inhibited growth of secondary and tertiary follicles while $2 \mathrm{mg} \mathrm{DHT} / \mathrm{kg}$ failed to block follicle development (Bagnell et al., 1982; Mahesh et al., 1987). Bagnell et al. (1982) reported that, in DHT-treated, hypophysectomized rat ovaries, the number of atretic secondary follicles increased with a concurrent rise in the number of primary follicles. Co-treatment with oestrogen prevented the decrease in the ovulation rate and the histological profile of the androgen plus oestrogentreated rats was similar to that of the controls. These experiments therefore demonstrated that DHT caused an increase in atresia among secondary follicles and that oestrogen reversed the detrimental effects of the androgen.

The action of DHT to decrease the ovulation rate could be caused either by the androgen acting on the pituitary to suppress the gonadotrophin surge or via a direct action on the ovaries. We have determined (unpublished) that, after a single subcutaneous injection of DHT, blood concentrations were maximal at $1 \mathrm{~h}$ but the androgen was cleared from the blood by $6 \mathrm{~h}$. It therefore seems unlikely that DHT is acting directly on the pituitary since the androgen is cleared in less than $6 \mathrm{~h}$ and the gonadotrophin surge starts nearly $20 \mathrm{~h}$ after the last injection. Furthermore, appropriate statistical analysis of the circulating concentrations of LH and FSH in the DHT-treated and control rats showed that the androgen has no effect on the pattern of secretion of either gonadotrophin (Figs 2a, 2b). Rather, it must be concluded that the androgen is acting directly on the follicles. The idea of a direct steroid effect is further supported by the observation that, when oestrogen is co-administered with DHT (Table 2), the expected decrease in the number of ovulations failed to occur. Other investigators (Payne \& Hellbaum, 1955; McNatty et al., 1979; Richards \& Kersey, 1979; Braw et al., 1981) have likewise concluded that adequate oestrogen production is essential to follicular development.

Two theories exist as to the vulnerability of follicles in their growth and development. Byskov (1974, 1979) and Ryan (1981) have claimed that atresia is random, can ensue at any time and is not specific to any stage of follicular development. Other investigators (Richards \& Midgley, 1976; Richards et al., 1978; Hirshfield \& Midgley, 1978a; Hirshfield \& Schmidt, 1987) point to a specific period of vulnerability during which follicles may become atretic. Butcher \& Kirkpatrick-Keller (1984) demonstrated that, in cyclic rats, atresia does not occur randomly and is uncommon in follicles $<100 \mu \mathrm{m}$ or $>400 \mu \mathrm{m}$ but occurs predominantly in follicles $100-400 \mu \mathrm{m}$ in diameter. Similarly, Hirshfield (1988) reported that the greatest rate of atresia was in follicles $300-350 \mu \mathrm{m}$ in cyclic rats. In follicles induced to grow with diethylstilboestrol in hypophysectomized rats, atresia was often greater than $50 \%$ in follicles $200-400 \mu \mathrm{m}$ in diameter (Sadrkhanloo et al., 1987). It is from these intermediate size follicles that ovulatory follicles in the next cycle are selected (Hirshfield \& Midgley, 1978b; Hirshfield, 1981; Hirshfield, 1984). In the present studies, ovulation rates in cycles subsequent to the treatment cycle were examined to determine whether DHT affects all follicle sizes. It was reasoned that follicles which ovulate in subsequent cycles have advanced from follicles that were $200-400 \mu \mathrm{m}$ in size during the treatment (first) cycle. Furthermore, the surge of LH during the first cycle (52-60 h after PMSG) would trigger ovulation of the large follicles while the accompanying surge of FSH would recruit smaller follicles to grow (Schwartz, 1974) and 
ovulate in the next cycle (Hirshfield \& Midgley, 1978b; Hirshfield, 1983). In the present study, when the androgen was given for $36 \mathrm{~h}$ after PMSG treatment, large preovulatory follicles were the most affected in Cycle 1 . However, smaller follicles $(200-400 \mu \mathrm{m})$ which would ovulate in later cycles were also affected since ovulation rates in the subsequent cycles were reduced as well (Fig. 3 ). This suggests that a period of androgen sensitivity exists and that period may encompass a wider range of follicular sizes than has been previously considered.

Although the present method of follicle isolation is rapid, it had to be established that the number of isolated follicles accurately reflects the number present in the ovary. When the ovaries of PMSG- and DHT-treated or control rats were analysed histologically, about 160-180 follicles were present per ovary with about $50 \%$ classed as primary, $32 \%$ secondary, $6 \%$ tertiary and $12-25 \%$ atretic (Fig. 1). If the primary, secondary and tertiary follicles roughly correspond to follicles of size ranges $<200 \mu \mathrm{m}, 200-400 \mu \mathrm{m}$ and $>400 \mu \mathrm{m}$, then there is good agreement between the histological method and isolation method for assessing the size of the follicle population (Fig. 5a). Any discrepancies between the estimates from the two methods may lie in the failure of the isolation method to distinguish between atretic and healthy follicles. Our findings of 160-180 follicles per ovary generally agree with Hirshfield (1988) but fall below the estimates of $250-300$ follicles per ovary by Butcher \& Kirkpatrick-Keller (1984).

In the present studies, fewer granulosa cells were found per follicle in ovaries from DHT-treated animals than from control animals. This reduction in granulosa cell numbers per follicle without a reduction in total number of follicles means that DHT treatment may reduce the rate at which granulosa cells proliferate. Using autoradiographic techniques, Hirshfield \& Schmidt (1987) have shown that healthy follicles of a known size contain a predictable number of granulosa cells and that atresia is accompanied by reduced numbers of granulosa cells per follicle. In the present experiments, the number of granulosa cells in the ovaries of the DHT-treated rats may have fallen below the minimum number required to prevent atresia so the follicles fail to ovulate in response to the LH surge.

In the studies presented herein, granulosa cells from follicles $<200 \mu \mathrm{m}$ synthesized significant amounts of oestradiol when incubated with testosterone and an NADPH-generating system. Roy \& Greenwald (1987) likewise reported that even the smallest follicles with few granulosa cells and no thecal cells made some steroids including oestrogens provided that the appropriate substrate was supplied. Figure 5(d) shows that DHT treatment reduces the oestrogen producing abilities of the granulosa cells of all follicle sizes, including those $<200 \mu \mathrm{m}$, by suppression of aromatase activity. Our findings that DHT inhibits aromatase activity seem to be at odds with those of Daniel \& Armstrong (1980) who reported DHT enhancement of the enzyme activity. These authors based their findings on granulosa cells from untreated immature rats cultured with FSH with and without DHT. Such granulosa cells may not be comparable to the cells from the immature rats treated in vivo with PMSG and DHT (Fig. 5d). By injecting PMSG into the animals, the granulosa cells are exposed not only to $\mathrm{FSH}$ and some $\mathrm{LH}$ stimulation, but also to a variety of paracrine regulatory factors from adjacent thecal cells or carried in the blood stream. Also of interest in this respect is the publication of Harlow et al. (1988) in which DHT enhanced aromatase in granulosa cells isolated from small follicles of the marmoset ovary but the androgen was inhibitory for the cells from large follicles. The authors interpret this to mean that, in more differentiated granulosa cells, DHT is inhibitory while in less differentiated cells the androgen is stimulatory. PMSG stimulation of immature rats may lead to some differentiation in the granulosa cells of all sizes of follicles and may make them sensitive to the inhibitory actions of DHT (Fig. 5d).

From these studies, we conclude that the decrease in ovulation rate in DHT-treated animals is due to a reduction in the number of granulosa cells per follicle as well as an impairment of the oestrogen synthetic abilities of the granulosa cells. The resulting decrease in oestrogen production causes, or is symptomatic of, greater follicular atresia. With increased atresia, there are fewer healthy follicles to ovulate in response to the gonadotrophin and fewer intermediate size follicles to ovulate in subsequent cycles. 
We thank Vivienne S. Stopper for excellent technical assistance. Supported in part by HD24488.

\section{References}

Bagnell, C.A., Mills, T.M., Costoff, A. \& Mahesh, V.B. (1982) A model for the study of androgen effects on follicular atresia and ovulation. Biol. Reprod. 27, 903-914.

Braw, R.H., Bar-Ami, S. \& Tsafriri, A. (1981) Effect of hypophysectomy on atresia of rat preovulatory follicles. Biol. Reprod. 25, 989-996.

Burdick, H.O. \& Whitney, R. (1941) Ovulation induced in mice by single injections of follutein or untreated human pregnancy urine. Am. J. Physiol. 132, 405-410.

Butcher, R.L. \& Kirkpatrick-Keller, D. (1984) Patterns of follicular growth during the four-day estrous cycle of the rat. Biol. Reprod. 31, 280-286.

Byskov, A.G.S. (1974) Cell kinetic studies of follicular atresia in the mouse ovary. J. Reprod. Fert. 37, $277-285$.

Byskov, A.G.S. (1978) Follicular atresia. In The Vertebrate Ovary, pp. 533-562. Ed. R. E. Jones. Plenum Press, New York.

Byskov, A.G.S. (1979) Atresia. In Ovarian Follicle Development and Function, pp. 41-57. Eds A. R. Midgley \& W. A. Sadler. Raven Press, New York.

Campbell, K.L. (1979) Ovarian granulosa cells isolated with EGTA and hypertonic sucrose: cellular integrity and function. Biol. Reprod. 21, 773-786.

Daniel, S.A.J. \& Armstrong, D.T. (1980) Enhancement of follicle stimulating hormone-induced aromatase activity by androgens in cultured rat granulosa cells. Endocrinology 107, 1027-1033.

Farookhi, R. (1980) Effects of androgen on induction of gonadotropin receptors and gonadotropin-stimulated adenosine $3^{\prime}, 5^{\prime}$-monophosphate production in rat ovarian granulosa cells. Endocrinology 106, $1216-1223$.

Goodman, A.L. \& Hodgen, G.D. (1983) The ovarian triad of the primate menstrual cycle. Recent Prog. Horm. Res. 39, 1-67.

Harlow, C.R., Shaw, H.J., Hillier, S.G. \& Hodges, J.K. (1988) Factors influencing follicle-stimulating hormone-responsive steroidogenesis in marmoset granulosa cells: effect of androgen and the stage of follicular maturity. Endocrinology 122, 2780-2787.

Harman, S.M., Louvet, J.P. \& Ross, G.T. (1975) Interaction of estrogen and gonadotropins on follicular atresia. Endocrinology 96, 1145-1152.

Hillier, S.G. \& Ross, G.T. (1979) Effects of exogenous testosterone on ovarian weight, follicular morphology and intraovarian progesterone concentration in estrogen-primed hypophysectomized immature female rats. Biol. Reprod. 20, 261-268.

Hirshfield, A.N. (198I) Role of FSH in the selection of ovulatory follicles. In Dynamics of Ovarian Function, pp. 79-82. Eds N. B. Schwartz \& M. HunzickerDunn. Raven Press, New York.

Hirshfield, A.N. (1983) Compensatory ovarian hypertrophy in the long-term hemicastrate rat: Size distribution of growing and atretic follicles. Biol. Reprod. 28, 271-278.
Hirshfield, A.N. (1984) Stathmokinetic analysis of granulosa cell proliferation in antral follicles of cyclic rats. Biol. Reprod. 31, 52-58.

Hirshfield, A.N. (1988) Size-frequency analysis of atresia in cycling rats. Biol. Reprod. 38, 1181-1188.

Hirshfield, A.N. \& Midgley, A.R. (1978a) Morphometric analysis of follicular development in the rat. Biol. Reprod. 19, 597-605.

Hirshfield, A.N. \& Midgley, A.R. (1978b) The role of FSH in the selection of large ovarian follicles in the rat. Biol. Reprod. 19, 606-611.

Hirshfield, A.N. \& Schmidt, W.A. (1987) Kinetic aspects of follicular development in the rat. In Regulation of Ovarian and Testicular Function, pp. 211-236. Eds V. B. Mahesh, D. S Dhindsa, E. Anderson \& S. P. Kalra. Plenum Press, New York.

Jia, C., Kessel, B., Welsh, T.H. \& Hsueh, A.J. (1985) Androgen inhibition of follicle-stimulating hormone stimulated luteinizing hormone receptor formation in cultured rat granulosa cells. Endocrinology 117, 13-22.

Kohut, J.K., Jarrell, J.F. \& YoungLai, E.V. (1985) Does dihydrotestosterone induce atresia in the hypophysectomized immature female rat treated with pregnant mare's serum gonadotropin? $\mathrm{Am}$. J. Obstet. Gynecol. 151, 250-255.

Louvet, J.P., Harman, S.M., Schreiber, J.R. \& Ross, G.T. (1975) Evidence for a role of androgens in follicular maturation. Endocrinology 97, 366-372.

Mahesh, V.B., Mills, T.M., Bagnell, C.A. \& Conway, B.A. (1987) Animal models for study of polycystic ovaries and ovarian atresia. In Regulation of $O$ varian and Testicular Function, pp. 237-257. Eds V. B. Mahesh, D. S. Dhindsa, E. Andersen \& S. P. Kalra. Plenum Publishing, New York.

MeNatty, K.P., Makris, A., DeGrazia, C., Osathanondh, R. \& Ryan, K.J. (1979) The production of progesterone, androgens and oestrogens by human granulosa cells in vitro and in vivo. J. Steroid Biochem. 11, $775-779$.

Melner, M.H. \& Abney, T.O. (1980) Depletion of the cytoplasmic estrogen receptor in gonadotropindesensitized testes. Endocrinology 107, 1620-1626.

O'Conner, J.L., Wolfe, R.R., Allen, M.B. \& Mahesh, V.B. (1982) Effect of neonatal androgenization on the LHRH response of dispersed pituitary cell cultures. Archs Androl. 8, 29-35.

Payne, R.W. \& Hellbaum, A.A. (1955) The effect of estrogens on the ovary of hypophysectomized rat. Endocrinology 57, $193-199$.

Pedersen, T. \& Peters, H. (1968) Proposal for a classification of oocytes and follicles in the mouse ovary. $J$. Reprod. Fert. 17, 555-557.

Rao, I.M. \& Mahesh, V.B. (1986) Role of progesterone in the modulation of the preovulatory surge of gonadotropins and ovulation in the pregnant mare's serum gonadotropin-primed immature rat and the adult rat. Biol. Reprod. 35, 1154-1161. 
Richards, J.S. (1979) Hormonal control of ovarian follicular development: a 1978 perspective. Recent Prog. Horm. Res. 35, 343-373.

Richards, J.S. \& Kersey, K.A. (1979) Changes in theca and granulosa cell function in antral follicles developing during pregnancy in the rat: gonadotropin receptors, cyclic AMP and estradiol-17\%. Biol. Reprod. 21, 1185-1201.

Richards, J.S. \& Midgley, A.R. (1976) Protein hormone action: a key to understanding ovarian follicular and luteal cell development. Biol. Reprod. 14, 82-94.

Richards, J.S., Rao, M.C. \& Ireland, J.J. (1978) Actions of pituitary gonadotrophins on the ovary. In Control of Ovulation, pp. 197-216. Eds D. B. Crighton, N. B. Haynes, G. R. Foxcroft \& G. E. Lamming. Butterworth Scientific, London.

Roy, S.K. \& Greenwald, G.S. (1985) An enzymatic method for dissociation of intact follicles from the hamster ovary: histological and quantitative aspects. Biol. Reprod. 32, 203-215.
Roy, S.K. \& Greenwald, G.S. (1987) In vitro steroido. genesis by primary to antral follicles in the hamster during the periovulatory period: effects of folliclestimulating hormone, luteinizing hormone and prolactin. Biol. Reprod. 37, 39-46.

Ryan, R.J. (1981) Follicular atresia: Some speculation on biochemical markers and mechanism. In Dynamics of Ovarian Function, pp. 1-11. Eds N. B. Schwartz \& M. Hunzicker-Dunn. Raven Press, New York.

Sadrkhanloo, R., Hofeditz, C. \& Erickson, G.F. (1987) Evidence for widespread atresia in the hypophysectomized estrogen-treated rat. Endocrinology 120, $146-155$.

Schwartz, N.B. (1974) The role of FSH and LH and of their antibodies on follicle growth and on ovulation. Biol. Reprod. 10, 236-272.

Tukey, J.W. (1949) Comparing individual means in the analysis of variance. Biometrics 5, 99-114.

Received 12 January 1990 